Article

\title{
Lightweight Design Solutions in the Automotive Field: Environmental Modelling Based on Fuel Reduction Value Applied to Diesel Turbocharged Vehicles
}

\author{
Massimo Delogu *, Francesco Del Pero and Marco Pierini \\ Department of Industrial Engineering, University of Florence, Florence 50139, Italy; \\ francesco.delpero@unifi.it (F.D.P.); marco.pierini@unifi.it (M.P.) \\ * Correspondence: massimo.delogu@unifi.it; Tel.: +39-055-275-8733 \\ Academic Editor: Bhavik Bakshi \\ Received: 25 August 2016; Accepted: 7 November 2016; Published: 11 November 2016
}

\begin{abstract}
A tailored model for the assessment of environmental benefits achievable by "light-weighting" in the automotive field is presented. The model is based on the Fuel Reduction Value (FRV) coefficient, which expresses the Fuel Consumption (FC) saving involved by a $100 \mathrm{~kg}$ mass reduction. The work is composed of two main sections: simulation and environmental modelling. Simulation modelling performs an in-depth calculation of weight-induced FC whose outcome is the FRV evaluated for a wide range of Diesel Turbocharged (DT) vehicle case studies. Environmental modelling converts fuel saving to impact reduction basing on the FRVs obtained by simulations. Results show that for the considered case studies, FRV is within the range $0.115-0.143$ and $0.142-0.388 \mathrm{~L} / 100 \mathrm{~km} \times 100 \mathrm{~kg}$, respectively, for mass reduction only and powertrain adaptation (secondary effects). The implementation of FRVs within the environmental modelling represents the added value of the research and makes the model a valuable tool for application to real case studies of automotive lightweight LCA.
\end{abstract}

Keywords: automotive; fuel consumption; Fuel Reduction Value (FRV); Life Cycle Assessment (LCA); light-weighting; vehicle system dynamics

\section{Introduction}

Global society strongly depends on transportation and the development trends forecast a substantial growth in this sector over the coming decades [1]. Considering the European Union, transportation industry represents the second largest contributor to anthropogenic greenhouse gas (GHG) emissions, and around $20 \%$ of these emissions are caused by road transports [2]. In this context, light-duty vehicles account for approximately $10 \%$ of total energy use and GHG emissions $[3,4]$. Considering that the number of cars is expected to increase from roughly 700 million to two billion over the period 2000-2050 [5], a dramatic increase in gasoline and diesel demand with implications on energy security, climate change and urban air quality appears to be very likely [6-10]. For an Internal Combustion Engine (ICE) car, use stage is responsible for a relevant quota of total Life Cycle (LC) impact (e.g., 85\% in terms of Global Warming Potential (GWP)); the latter is mainly due to Fuel Consumption (FC), which strongly depends on vehicle mass [11-18].

"Light-weighting" is unanimously recognized as one of the key measures in order to lower car use stage FC and environmental burden [19-23]; on the other hand, the adoption of novel materials and innovative technologies often shifts the impacts to other LC stages (e.g., production and End-of-Life (EoL)) $[24,25]$. In this regard, plastics, composites, aluminium, high-strength steel and magnesium and sandwich materials are expected to play a leading role in the future. Aluminium, high-strength steel and composites can be used both in structural (i.e., frame or seat structure) and functional (i.e., steering or transmission) parts where strength is the key requirement; on the other hand, for interior parts, plastic will remain the predominant element and it will also become more important in the future, 
due to its favourable cost-weight ratio. On the other hand, even though light-weighting allows lowering use stage impact by reduction of FC, it usually involves negative effects on production and EoL stages [26-30]. Indeed, lightweight materials are usually more energy-intensive and involve higher $\mathrm{CO}_{2}$ emissions prior to operation if compared with conventional steel. At the same time, recycling of composites is still not a well-established practice, contrary to what happens for metals [11,31-34]. Therefore, a balance of benefits and disadvantages involved with light-weighting during the whole vehicle LC is needed. This allows quantifying the driving distance for which the reduced use stage FC compensates production and EoL emissions, thus involving actual benefits.

The Life Cycle Assessment (LCA) methodology is the most indicated approach for performing the environmental assessment of lightweight solutions. Many LCA studies already exist in the transportation sector [35-39] and interest is continuously growing, particularly in the automotive field [11,36,40-45].

Considering the automotive lightweight LCA context, literature provides several examples of comparative studies based on Fuel Reduction Value (FRV) coefficient $[2,37,46-48]$. The FRV adopted by current LCAs is comprised within the range $0.02-1.00 \mathrm{~L} / 100 \mathrm{~km} \times 100 \mathrm{~kg}$; this estimation derives from other works $[13,49-56]$ hat model mass-induced FC taking into account theoretical background and underlying physical correlations. From the review of this typology of studies, some considerations emerge. The researches are based on simulation modelling of a very restricted number of specific car models; therefore, the values of FRV are influenced by technical features of case studies without being really representative of entire vehicle classes or engine technologies. Furthermore, the existing works determine the FRV basing on standardized driving cycles [57-59]: the American researches generally refer to the Federal Test Procedure driving cycles [60] while the European ones to the NEDC [61]. Consequently, the reference cycle changes passing from one study to another, thus involving a relevant limitation in terms of comparability for the FRV value. Additionally, the adoption of a single cycle as basis for calculation strongly limits the reliability of results as no further driving styles are taken into account.

The proposed work is an extension of [49] and it refines an environmental model able to treat the use stage within the automotive lightweight LCA context in applications to Diesel Turbocharged (DT) vehicles; the aim is supporting LCA practitioners to evaluate the environmental benefits achievable by light-weighting in real case studies. Starting from the amount of mass reduction, the model estimates the avoided impacts through the Fuel Reduction Value (FRV) coefficient, which is determined by a simplified calculation procedure based on vehicle technical features. Such a procedure derives from an in-depth simulation modelling of car weight-induced FC which tries to fill the gaps of existing literature:

- $\quad$ FRV is estimated for a large number of vehicle case studies belonging to A/B, C and D classes; within each class, a wide range of car technical features is taken into account;

- Vehicle case studies are representative of 2015 European car market;

- $\quad$ FRV is evaluated based on the most globally widespread driving cycles;

- The analysis is extended to both Primary Mass Reduction only (PMR) and Secondary Effects (SE); in the case of SE, a valid criterion for their application is refined.

\section{Materials and Methods}

The construction of the model consists of three main stages. In the first stage, FC is calculated for various mass-configurations of a certain number of vehicle case studies; calculation is performed through simulation modelling of car dynamics. The second stage evaluates the mass-induced FC starting from the output of the first one; based on values of FC obtained for the different mass-configurations, mass-induced FC is determined through the relation between consumption and mass. The third stage consists in the conception of a tailored LCA model which implements mass-induced FC calculated in Stage 2 and provides as an output LCIA impacts. The following paragraphs describe in detail the three stages. 


\subsection{Calculation of Use Stage FC}

The calculation of use stage FC is performed through an AMESim simulation model. Below, the modelling is described in terms of model composition, driving cycles and range of vehicle case studies. The model estimates torque at wheels needed in order to follow the speed profile of driving cycle by simulating all components of vehicle drivetrain. The automotive network is subdivided into two sections: drive train (sub-models: engine, clutch, gearbox and vehicle dynamics) and control logic (sub-models: mission profile and ambient data, driver and control unit). The complete model is shown in Figure 1.

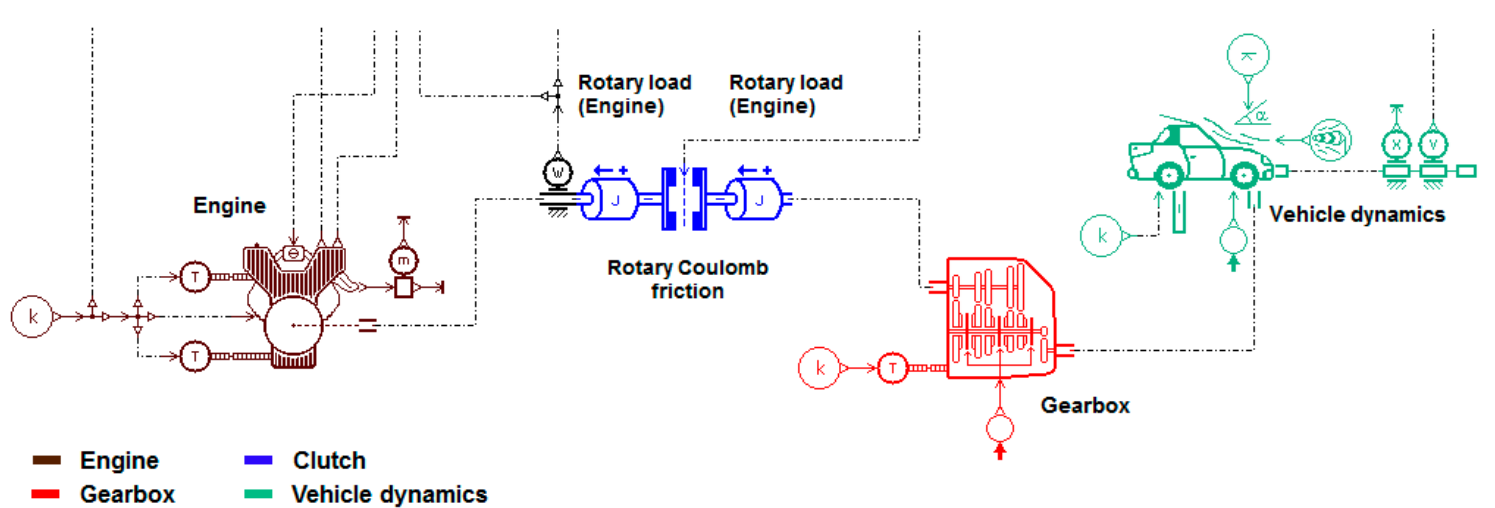

- Gearbox - Vehicle dynamics
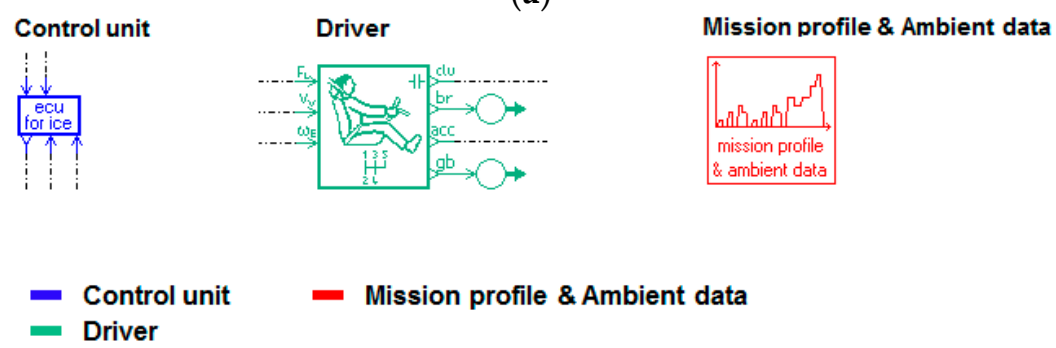

(b)

Figure 1. Use stage simulation model: drive train section (a); and control logic section (b).

The driving cycles assumed as reference for simulation are the following: Federal Test Procedure 72 (FTP72) [62], Japan 08 (JC08) [63], New European Driving Cycle (NEDC) [62] and World Light Test Cycle (WLTC) [57]. The first three cycles are the reference for current type approval test, respectively, in the U.S., Japan and Europe, while WLTC will substitute the NEDC in the coming years. The modelling is applied to a large number of DT vehicle case studies representative of different classes within the 2015 European car market, thus allowing the consideration of a certain variability of technical features within each class. The number of case studies (see Table 1) per vehicle class depends exclusively on the availability in literature of data needed for the setting of simulation model.

Table 1. Reference mass-configuration—variable model parameters: car models chosen as reference.

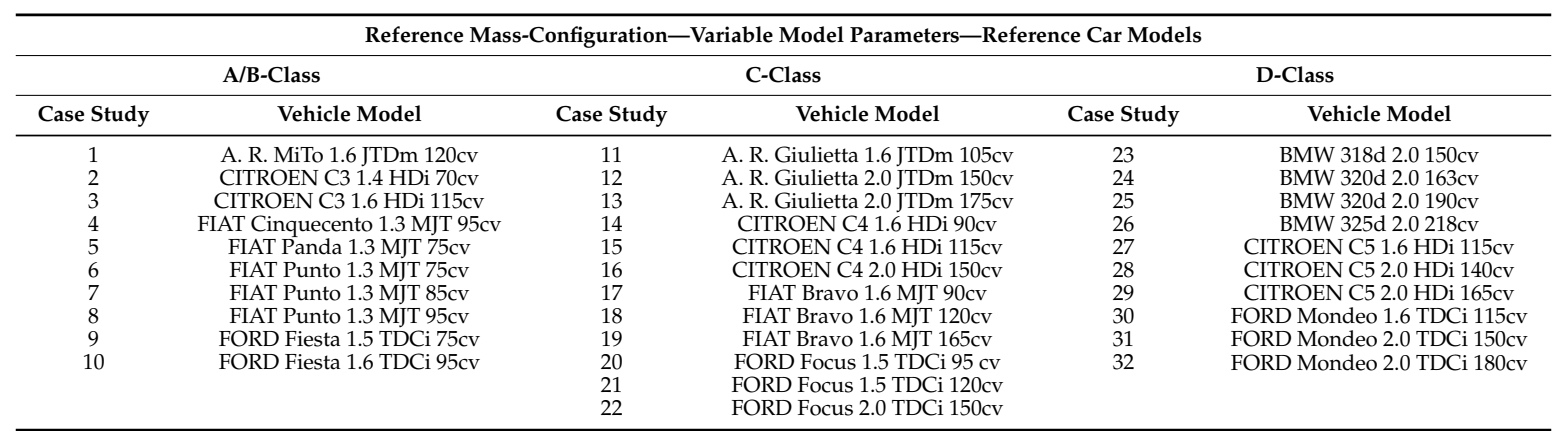




\subsection{Evaluation of Mass-Induced FC Reduction}

The evaluation of mass-induced FC is performed through the FRV coefficient. The procedure for calculating the FRV is described below separately between the cases of Primary Mass Reduction (PMR) and Secondary Effects (SE).

Primary Mass Reduction (PMR): Mass-induced FC is determined as the consumption saving achievable through car mass reduction only and it is calculated by Equation (1):

$$
F C_{\text {use_sav_PMR }}=F R V_{P M R} \times \text { mass }_{\text {sav }}
$$

where $F R V_{P M R}=$ Fuel Reduction Value in the case of Primary Mass Reduction $(\mathrm{L} / 100 \mathrm{~km} \cdot 100 \mathrm{~kg})$; $F C_{\text {use_sav_PMR }}=$ amount of Fuel Consumption saved during operation thanks to light-weighting in the case of Primary Mass Reduction $(\mathrm{L} / 100 \mathrm{~km})$; and mass $_{s a v}=$ saved mass thanks to light-weighting $(\mathrm{kg})$.

The FRV coefficient is estimated based on values of FC obtained in Stage 1. For each of the vehicle case studies, consumption is calculated for the following five mass-configurations: reference and $5 \%$, $10 \%, 15 \%$, and $20 \%$ lightweight. Starting from values of FC, the FRV is determined as the slope of regression line of consumption in function of mass. As the target is evaluating the effect of mass only, FC of lightweight configurations is estimated through the same simulation model, in which the only change is vehicle weight, and all others remain unaltered.

Secondary Effects (SE): Mass-induced FC is determined as the consumption saving achievable through car mass reduction with further interventions in the vehicle. It is calculated through Equation (2):

$$
F C_{\text {use_sav_SE }}=F R V_{S E} \times \text { mass }_{\text {sav }}
$$

where $F R V_{S E}=$ Fuel Reduction Value in the case of Secondary Effects $(\mathrm{L} / 100 \mathrm{~km} \times 100 \mathrm{~kg})$; $F C_{\text {use_sav_SE }}=$ amount of Fuel Consumption saved during operation thanks to light-weighting in the case of Secondary Effects $(\mathrm{L} / 100 \mathrm{~km})$; and mass $_{\text {sav }}=$ saved mass thanks to light-weighting $(\mathrm{kg})$.

$\mathrm{SE}$ are applied to lightweight configurations only and they consist in resizing vehicle powertrain in order that mass reduction is exclusively used for lowering FC while performance and technological levels remain unaltered. For performance level, the chosen criterion is the " $80-120 \mathrm{~km} / \mathrm{h}$ elasticity in the upper gear ratio". Technological level is represented by parameters Maximum Brake Mean Effective Pressure $\left(B M E P_{\max }\right)$, Stroke-to-Bore ratio $(S B R)$ and Mean Piston Speed $(M P S)$, whose analytical expressions are reported below (Equations (3)-(5)):

$$
\begin{gathered}
B M E P_{\max }=\frac{T_{\max } \times 4 \pi}{V} \\
S B R=\frac{\text { stroke }}{\text { bore }} \\
M P S=\frac{\text { stroke } \times \text { rpm }}{30}
\end{gathered}
$$

where $B M E P_{\max }=$ maximum Brake Mean Effective Pressure (bar); $T_{\max }=$ maximum engine torque $(\mathrm{Nm}) ; V=$ engine displacement $(\mathrm{L}) ; S B R=$ Stroke-to-Bore ratio (null); stroke = engine stroke $(\mathrm{m})$; bore $=$ engine bore $(\mathrm{m}) ; M P S=$ Mean Piston Speed $(\mathrm{m} / \mathrm{s}) ;$ and $r p m=$ engine speed $(\mathrm{rpm})$.

\subsection{Environmental Modelling}

The third stage consists in the conception of a tailored LCA model able to convert mass reduction to avoided use stage environmental impacts. The model takes into account both sub-stages that compose use stage: Well-To-Tank (WTT) (fuel transformation processes upstream to fuel consumption) and Tank-To-Wheel (TTW) (FC for car driving). In order to include both quota, a GaBi6 plan composed by WTT and TTW processes is conceived. In the construction of the plan, TTW process is completely modelled by an analytical parameterization of inputs/output flows while WTT process is taken from the GaBi6 process database (section "Energy conversion-Fuel production-Refinery products") without 
any modification. For this reason, hereinafter, the only TTW process is described in detail in terms of input/output flows and equations that model input/output flows. Table 2 shows TTW inputs/output flows and a qualitative description of them.

Table 2. Environmental model: Inputs/outputs and related GaBi6 flows of TTW process.

\begin{tabular}{|c|c|c|}
\hline & \multicolumn{2}{|l|}{ TTW Process } \\
\hline & Parameters & GaBi6 Flows \\
\hline INPUT & $\begin{array}{l}\text { Amount of Fuel Consumption saved during } \\
\text { operation thanks to light-weighting }\left(F C_{\text {use_sav }}\right)\end{array}$ & Diesel-Refinery products (kg) \\
\hline \multirow{3}{*}{ OUTPUT } & $\begin{array}{l}\text { Amount of biogenic } \mathrm{CO}_{2} \text { emission saved during } \\
\text { operation thanks to light-weighting }\left(\mathrm{CO}_{2 \mathrm{BIO} \_u s e \_s a v}\right)\end{array}$ & $\begin{array}{c}\text { Carbon dioxide (biotic)_Inorganic } \\
\text { emissions to air }(\mathrm{g})\end{array}$ \\
\hline & $\begin{array}{c}\text { Amount of fossil } \mathrm{CO}_{2} \text { emission saved during } \\
\text { operation thanks to } \\
\text { light-weighting }\left(\mathrm{CO}_{2 F O S \_u s e \_s a v}\right)\end{array}$ & $\begin{array}{c}\text { Carbon dioxide (fossil)_Inorganic } \\
\text { emissions to air }(\mathrm{g})\end{array}$ \\
\hline & $\begin{array}{c}\text { Amount of } \mathrm{SO}_{2} \text { emission saved during operation } \\
\text { thanks to light-weighting }\left(\mathrm{SO}_{2} \_ \text {use_sav }\right)\end{array}$ & $\begin{array}{l}\text { Sulphur dioxide-Inorganic } \\
\text { emissions to air }(\mathrm{kg})\end{array}$ \\
\hline
\end{tabular}

The equations that model input/output flows of TTW process are reported in Table 3.

Table 3. Environmental model: Basic equations of TTW process.

\begin{tabular}{|c|c|c|c|}
\hline & & TTW Equations & \\
\hline \multirow[t]{5}{*}{ INPUT } & $F C_{\text {use_sav }}$ & $F C_{\text {use_sav }}=\frac{F R V \times \text { mass }_{\text {sav }} \times \text { mileage }_{\text {use }}}{10000} \times \rho_{\text {fuel }}$ & (6) \\
\hline & & $\mathrm{CO}_{2 B I O \_u s e \_s a v}=\mathrm{CO}_{2 B I O \_v e h \_k m} \times$ mileage $_{u s e} \times \frac{F C_{\text {use_sav }}}{F C_{\text {use_veh }}}$ & (7) \\
\hline & & Where: & \\
\hline & & $\mathrm{CO}_{2 \mathrm{BIO} \_ \text {veh_km }}=\mathrm{CO}_{2 \_ \text {veh } \mathrm{km}} \times$ share $\mathrm{CO}_{2 \mathrm{BIO}}$ & (8) \\
\hline & & $\begin{array}{c}\mathrm{CO}_{2 \_v e h \_k m}=\text { share }_{m w} \times \mathrm{CO}_{2 \_v e h \_k m \_m w}+ \\
\text { share }_{r u} \times \mathrm{CO}_{2 \_v e h \_k m \_r u}+\text { share }_{u r} \times \mathrm{CO}_{2 \_v e h \_k m \_u r}\end{array}$ & (9) \\
\hline \multirow[t]{4}{*}{ OUTPUT } & & $F C_{\text {use_veh }}=\frac{F C_{\text {veh_1 } 100 \mathrm{~km}}}{100} \times$ mileage $e_{\text {use }} \times \rho_{\text {fuel }}$ & $(10)$ \\
\hline & & $\mathrm{CO}_{2 F O S_{\_} \text {use_sav }}=\mathrm{CO}_{2 \mathrm{FOS} \_v e h \_k m} \times$ mileage $_{\text {use }} \times \frac{F C_{\text {use_sav }}}{F C_{\text {use_veh }}}$ & $(11)$ \\
\hline & $\mathrm{CO}_{2 F O S \_u s e \_s a v}$ & Where: & \\
\hline & & $\mathrm{CO}_{2 F O S \_v e h \_k m}=\mathrm{CO}_{2 \_ \text {_veh_km }} \times\left(1-\right.$ share $\left.\mathrm{CO}_{2 \mathrm{BIO}}\right)$ & $(12)$ \\
\hline
\end{tabular}


Table 3. Cont.

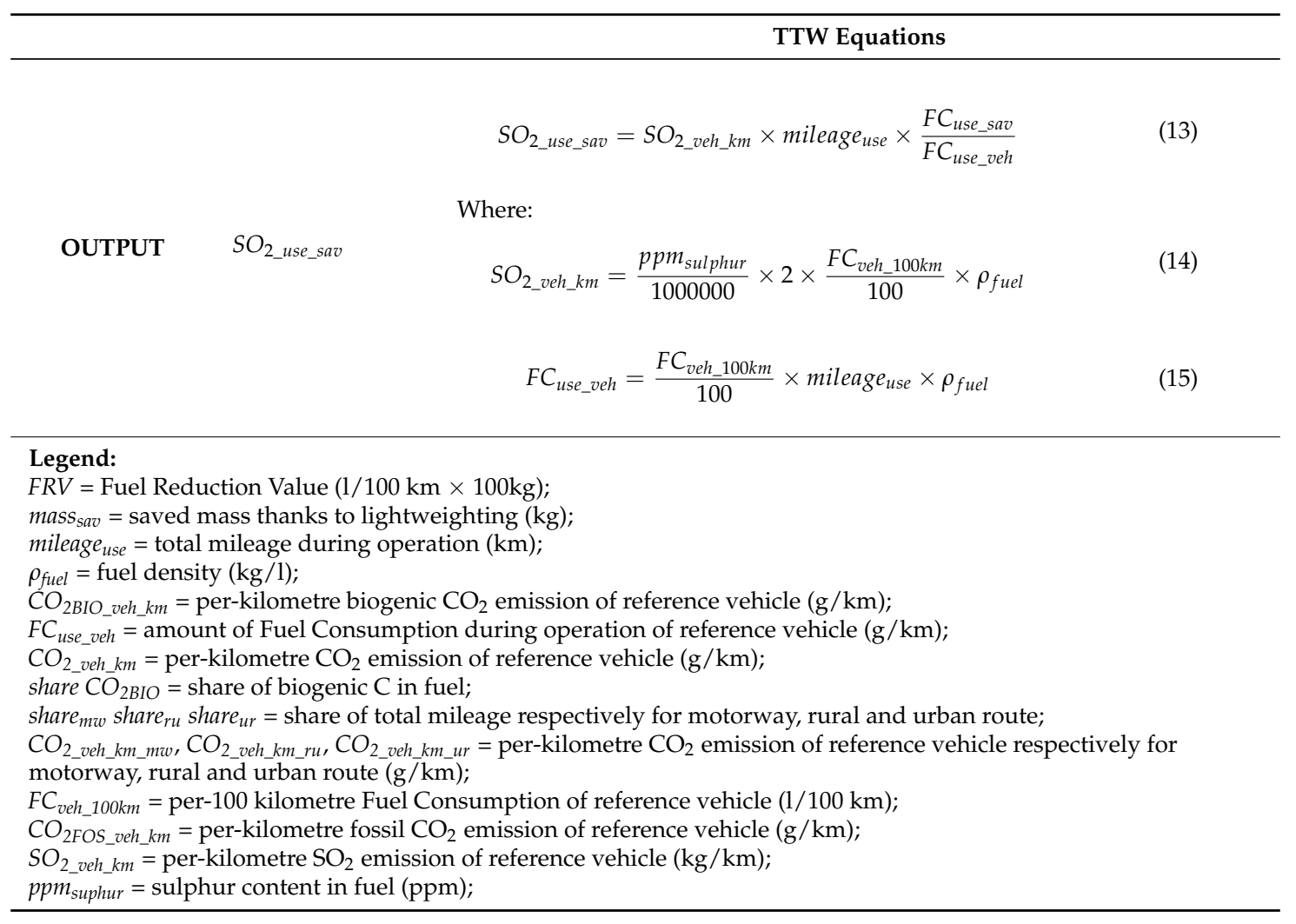

The environmental model is customizable for the specific case study through the setting of the following parameters:

- $\mathrm{CO}_{2 \_v e h \_k m}$ and $\mathrm{SO}_{2 \_ \text {veh_km }}$ are taken from the GaBi6 process database (section "Transport-Road-Passenger car") depending on emission standard, engine size and technology of the specific case study;

- $\quad F R V$ is an output of Stage 2 "Evaluation of mass-induced FC reduction" and it is chosen depending on the specific case study through the criteria identified in Section 3.2;

- $\quad \rho_{\text {fuel }}$, mileage $_{\text {use }}, p p m_{\text {sulphur }}$, and share $\mathrm{CO}_{2 \mathrm{BIO}}$ are taken from the GaBi6 process database depending on fuel type of the specific case study;

- $\quad F C_{\text {veh } 100 \mathrm{~km}}$, mass $_{\text {saved }}$, mileage $_{u s e}$, share $_{m w}$, share $_{r u}$, and share $_{u r}$ depend on the specific case study.

\section{Results, Interpretation and Discussion}

Results, interpretation and discussion are subdivided into two main sections: simulation and environmental modelling.

\subsection{Simulation Modelling}

Fuel Reduction Value: analysis of results. Table 4 reports the FRV for all case studies. Data are presented for both PMR $\left(F R V_{P M R}\right)$ and SE $\left(F R V_{S E}\right)$. Within each of them, five values are reported: four values calculated with respect to driving cycles assumed as reference for the study $\left(F R V_{F T P 72}\right.$, $F R V_{J C 08}, F R V_{N E D C}$, and $F R V_{\text {WLTC }}$; and one value calculated as the arithmetic mean of $F R V_{F T P 72}$, $F R V_{J C 08}, F R V_{N E D C}$, and $F R V_{\text {WLTC }}\left(F R V_{\text {MeanCycles }}\right)$. 
Table 4. Fuel Reduction Value for the considered case studies $(\mathrm{L} / 100 \mathrm{~km} \times 100 \mathrm{~kg})$

\begin{tabular}{|c|c|c|c|c|c|c|c|c|c|c|c|}
\hline \multirow[b]{3}{*}{ Vehicle Class } & \multirow[b]{3}{*}{ Case Study } & \multicolumn{10}{|c|}{$F R V(\mathrm{~L} / 100 \mathrm{~km} \times 100 \mathrm{~kg})$} \\
\hline & & \multicolumn{5}{|c|}{ PMR } & \multicolumn{5}{|c|}{ SE } \\
\hline & & $\begin{array}{c}\text { FTP72 } \\
\left(F R V_{F T P 72 \_P M R}\right) \\
\end{array}$ & $\begin{array}{c}\mathrm{JC} 08 \\
\left(F R V_{\text {JCOS_PMR }}\right)\end{array}$ & $\begin{array}{c}\text { NEDC } \\
\left(F R V_{N E D C \_P M R}\right) \\
\end{array}$ & $\begin{array}{c}\text { WLTC } \\
\left(F R V_{\text {WLTC_PMR }}\right)\end{array}$ & $\begin{array}{l}\text { Mean Cycles } \\
(\text { (FRV }\end{array}$ & $\begin{array}{c}\text { FTP72 } \\
\left(F R V_{F T P 72 \_S E}\right) \\
\end{array}$ & $\begin{array}{c}\mathrm{JC08} \\
\left(\text { FRV } V_{\text {ICOS_SE }}\right)\end{array}$ & $\begin{array}{c}\text { NEDC } \\
\left(F R V_{\text {NEDC_SE }}\right) \\
\end{array}$ & $\begin{array}{c}\text { WLTC } \\
\left(F R V_{\text {WLTC_SE }}\right) \\
\end{array}$ & $\begin{array}{l}\text { Mean Cycles } \\
\left(F R V_{\text {MeanCycles_SE })}\right.\end{array}$ \\
\hline $\mathrm{A} / \mathrm{B}$ & $\begin{array}{c}1 \\
2 \\
3 \\
4 \\
5 \\
6 \\
7 \\
8 \\
9 \\
10 \\
\end{array}$ & $\begin{array}{l}0.173 \\
0.153 \\
0.174 \\
0.149 \\
0.145 \\
0.147 \\
0.150 \\
0.150 \\
0.149 \\
0.149 \\
\end{array}$ & $\begin{array}{l}0.165 \\
0.140 \\
0.157 \\
0.150 \\
0.151 \\
0.149 \\
0.153 \\
0.148 \\
0.143 \\
0.150 \\
\end{array}$ & $\begin{array}{l}0.148 \\
0.143 \\
0.145 \\
0.137 \\
0.146 \\
0.136 \\
0.130 \\
0.129 \\
0.137 \\
0.137 \\
\end{array}$ & $\begin{array}{l}0.146 \\
0.115 \\
0.148 \\
0.117 \\
0.122 \\
0.116 \\
0.120 \\
0.117 \\
0.129 \\
0.117 \\
\end{array}$ & $\begin{array}{l}0.158 \\
0.138 \\
0.156 \\
0.138 \\
0.141 \\
0.137 \\
0.138 \\
0.136 \\
0.140 \\
0.138 \\
\end{array}$ & $\begin{array}{l}0.295 \\
0.217 \\
0.281 \\
0.253 \\
0.239 \\
0.235 \\
0.246 \\
0.250 \\
0.227 \\
0.253 \\
\end{array}$ & $\begin{array}{l}0.284 \\
0.212 \\
0.275 \\
0.245 \\
0.237 \\
0.235 \\
0.240 \\
0.241 \\
0.226 \\
0.245 \\
\end{array}$ & $\begin{array}{l}0.270 \\
0.194 \\
0.259 \\
0.224 \\
0.218 \\
0.215 \\
0.213 \\
0.221 \\
0.207 \\
0.224 \\
\end{array}$ & $\begin{array}{l}0.253 \\
0.142 \\
0.220 \\
0.214 \\
0.173 \\
0.202 \\
0.225 \\
0.223 \\
0.166 \\
0.214 \\
\end{array}$ & $\begin{array}{l}0.276 \\
0.191 \\
0.259 \\
0.234 \\
0.217 \\
0.222 \\
0.231 \\
0.234 \\
0.207 \\
0.234 \\
\end{array}$ \\
\hline c & $\begin{array}{l}11 \\
12 \\
13 \\
14 \\
15 \\
16 \\
17 \\
18 \\
19 \\
20 \\
21 \\
22 \\
\end{array}$ & $\begin{array}{l}0.168 \\
0.180 \\
0.171 \\
0.154 \\
0.166 \\
0.174 \\
0.165 \\
0.167 \\
0.179 \\
0.160 \\
0.166 \\
0.179 \\
\end{array}$ & $\begin{array}{l}0.159 \\
0.167 \\
0.161 \\
0.146 \\
0.157 \\
0.160 \\
0.153 \\
0.159 \\
0.170 \\
0.154 \\
0.157 \\
0.162 \\
\end{array}$ & $\begin{array}{l}0.148 \\
0.154 \\
0.149 \\
0.142 \\
0.149 \\
0.156 \\
0.140 \\
0.149 \\
0.154 \\
0.141 \\
0.153 \\
0.163 \\
\end{array}$ & $\begin{array}{l}0.141 \\
0.152 \\
0.143 \\
0.137 \\
0.138 \\
0.144 \\
0.138 \\
0.136 \\
0.150 \\
0.133 \\
0.137 \\
0.147 \\
\end{array}$ & $\begin{array}{l}0.154 \\
0.163 \\
0.156 \\
0.145 \\
0.153 \\
0.159 \\
0.149 \\
0.153 \\
0.163 \\
0.147 \\
0.153 \\
0.163 \\
\end{array}$ & $\begin{array}{l}0.262 \\
0.294 \\
0.291 \\
0.245 \\
0.261 \\
0.281 \\
0.289 \\
0.273 \\
0.294 \\
0.273 \\
0.259 \\
0.286 \\
\end{array}$ & $\begin{array}{l}0.253 \\
0.282 \\
0.280 \\
0.247 \\
0.252 \\
0.266 \\
0.269 \\
0.259 \\
0.283 \\
0.258 \\
0.246 \\
0.268 \\
\end{array}$ & $\begin{array}{l}0.235 \\
0.266 \\
0.270 \\
0.233 \\
0.231 \\
0.252 \\
0.246 \\
0.245 \\
0.269 \\
0.240 \\
0.234 \\
0.249 \\
\end{array}$ & $\begin{array}{l}0.214 \\
0.240 \\
0.243 \\
0.206 \\
0.206 \\
0.214 \\
0.233 \\
0.220 \\
0.239 \\
0.216 \\
0.196 \\
0.216 \\
\end{array}$ & $\begin{array}{l}0.241 \\
0.271 \\
0.271 \\
0.233 \\
0.238 \\
0.253 \\
0.259 \\
0.249 \\
0.271 \\
0.247 \\
0.234 \\
0.255 \\
\end{array}$ \\
\hline D & $\begin{array}{l}23 \\
24 \\
25 \\
26 \\
27 \\
28 \\
29 \\
30 \\
31 \\
32\end{array}$ & $\begin{array}{l}0.187 \\
0.220 \\
0.226 \\
0.243 \\
0.156 \\
0.169 \\
0.184 \\
0.166 \\
0.197 \\
0.212\end{array}$ & $\begin{array}{l}0.168 \\
0.189 \\
0.188 \\
0.182 \\
0.149 \\
0.161 \\
0.170 \\
0.159 \\
0.170 \\
0.184\end{array}$ & $\begin{array}{l}0.158 \\
0.170 \\
0.172 \\
0.168 \\
0.143 \\
0.153 \\
0.158 \\
0.151 \\
0.160 \\
0.171\end{array}$ & $\begin{array}{l}0.150 \\
0.175 \\
0.168 \\
0.173 \\
0.131 \\
0.149 \\
0.156 \\
0.141 \\
0.148 \\
0.169\end{array}$ & $\begin{array}{l}0.166 \\
0.189 \\
0.189 \\
0.192 \\
0.145 \\
0.158 \\
0.167 \\
0.154 \\
0.169 \\
0.184\end{array}$ & $\begin{array}{l}0.297 \\
0.340 \\
0.346 \\
0.388 \\
0.243 \\
0.257 \\
0.294 \\
0.266 \\
0.291 \\
0.323\end{array}$ & $\begin{array}{l}0.273 \\
0.298 \\
0.305 \\
0.320 \\
0.246 \\
0.259 \\
0.277 \\
0.260 \\
0.264 \\
0.294\end{array}$ & $\begin{array}{l}0.259 \\
0.278 \\
0.287 \\
0.300 \\
0.232 \\
0.244 \\
0.261 \\
0.244 \\
0.243 \\
0.271\end{array}$ & $\begin{array}{l}0.224 \\
0.253 \\
0.249 \\
0.292 \\
0.197 \\
0.212 \\
0.232 \\
0.207 \\
0.208 \\
0.237\end{array}$ & $\begin{array}{l}0.263 \\
0.292 \\
0.297 \\
0.325 \\
0.230 \\
0.243 \\
0.266 \\
0.244 \\
0.252 \\
0.281\end{array}$ \\
\hline
\end{tabular}


In summary, for each case study, the complete set of results is composed of 10 values for the FRV:

- $\quad$ PMR: $F R V_{F T P 72 \_P M R}, F R V_{J C 08 \_P M R}, F R V_{N E D C_{-} P M R}, F R V_{W L T C \_P M R}$, and $F R V_{\text {MeanCycles_PMR }}$; and - SE: FRV $\quad$ FTP72_SE $, F R V_{J C 08_{-} S E}, F R V_{\text {NEDC_SE, }}, F R V_{\text {WLTC_SE }}, F R V_{\text {MeanCycles_SE. }}$.

Figure 2 reports the arithmetic mean of FRV within the class per driving cycle: the black bars identify the maximum range of variation around the mean.
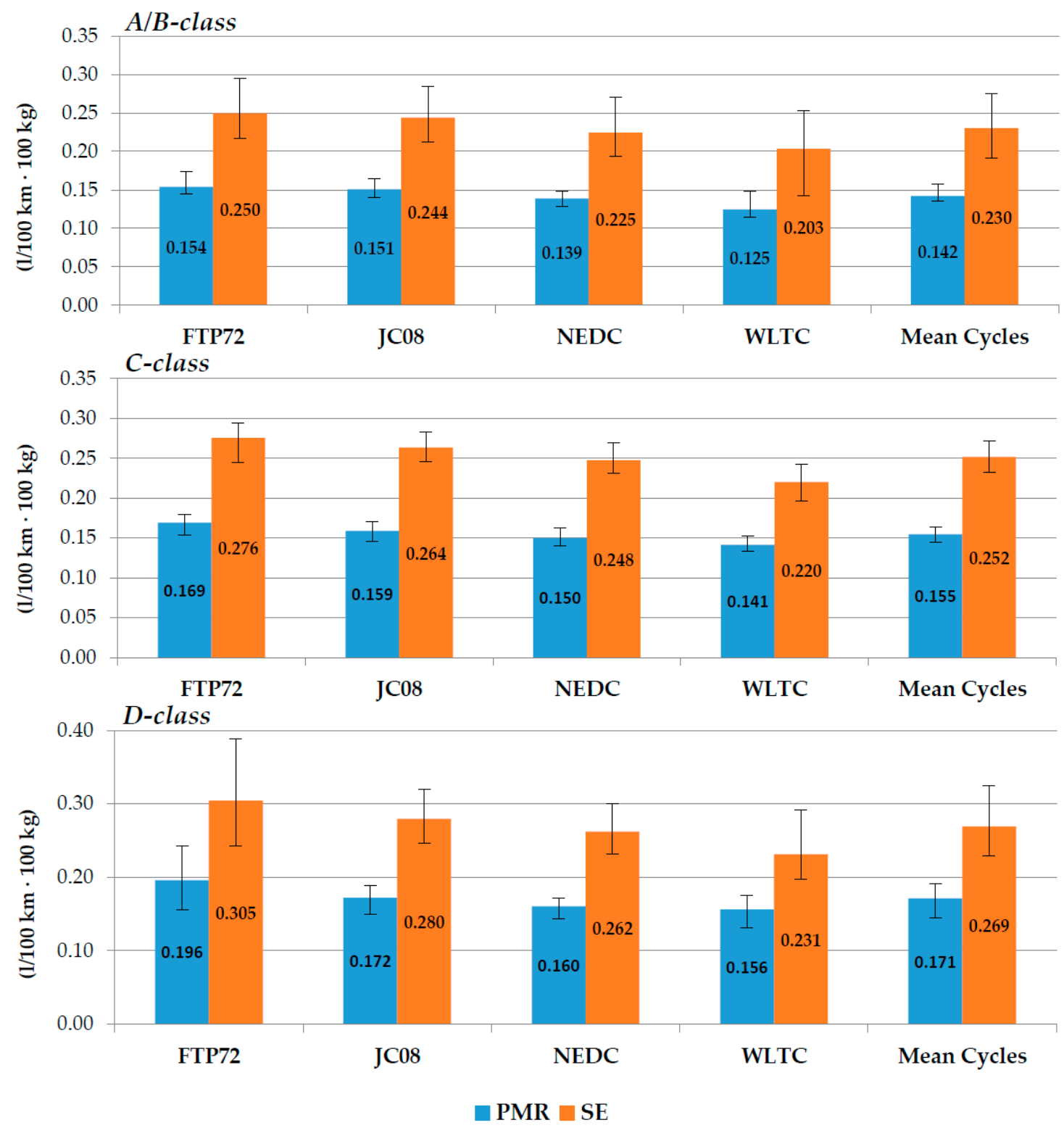

Figure 2. Arithmetic mean of FRV over case studies per driving cycle (L/100 km $\times 100 \mathrm{~kg})$.

Dependence of FRV on vehicle technical features. This paragraph aims to establish if any correlation between the values of FRV and the main vehicle technical features exists. The parameters taken into account are maximum Brake Mean Effective Pressure $\left(B M E P_{\max }\right)$, vehicle mass $\left(m_{v e h}\right)$, maximum Power $\left(P_{\max }\right)$ and Power-to-Mass Ratio $(P / M)$. The existence of any correlation is investigated through the analysis of regression lines of $F R V_{P M R}$ and $F R V_{S E}$ in function of $B M E P_{\max }, m_{v e h}, P_{\max }$ and $P / M$. Figure 3 reports regression lines and corresponding coefficient of determination for $F R V_{\text {Meancycles }}$. 

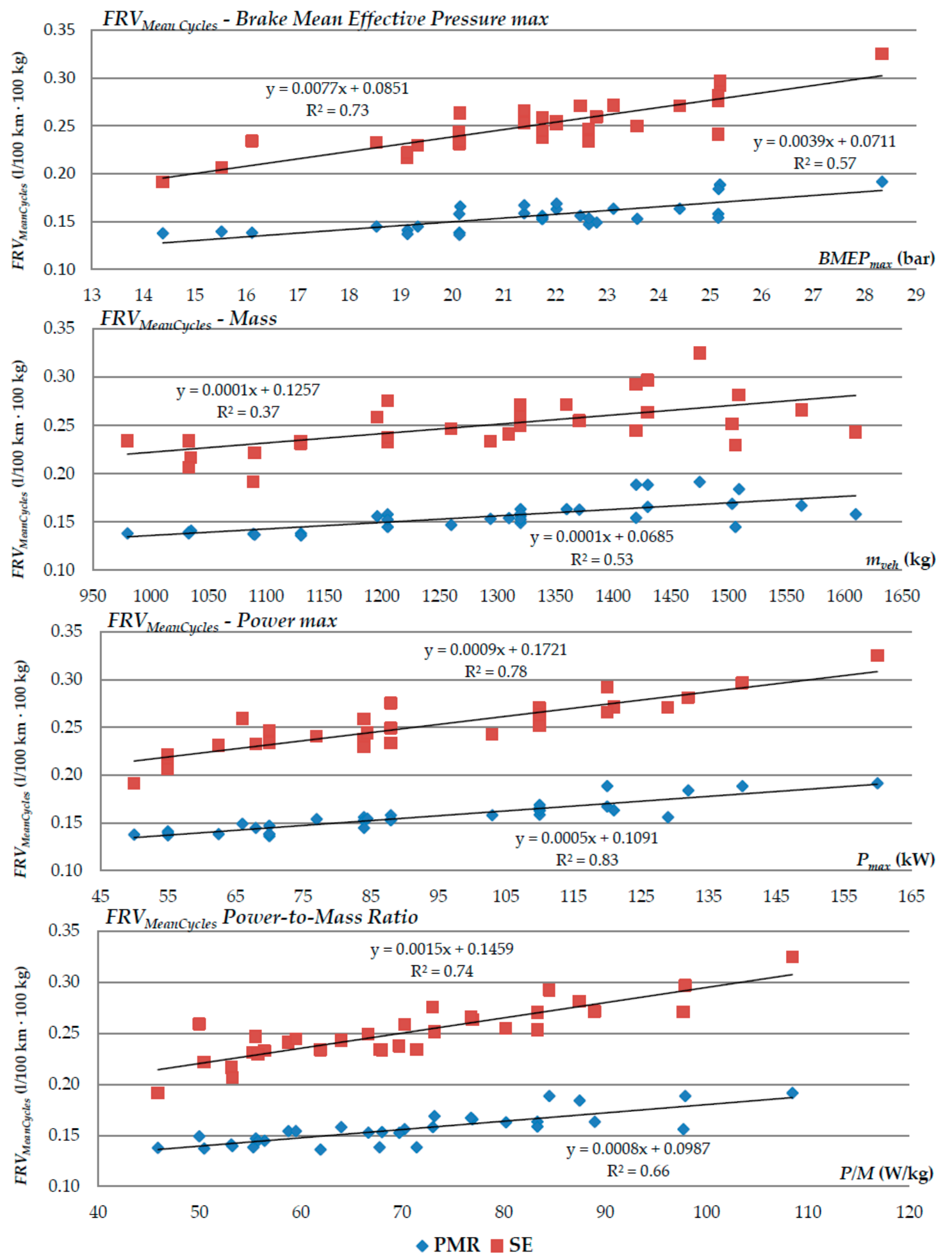

Figure 3. $F R V_{\text {Meancycles }}$ of all case studies in function of maximum Brake Mean Effective Pressure $\left(B M E P_{\max }\right)$, vehicle mass $\left(m_{v e h}\right)$, maximum Power $\left(P_{\max }\right)$ and Power-to-Mass Ratio $(P / M)$ with regression lines and corresponding coefficient of determination $\left(R^{2}\right)$.

Table 5 quantifies the effectiveness of correlation between FRV and vehicle parameters by reporting $\mathrm{R}^{2}$ of regression lines for $F R V_{F T P 72}, F R V_{J C 08}, F R V_{N E D C}, F R V_{\text {WLTC }}$ and $F R V_{\text {MeanCycles }}$. 
Table 5. Coefficient of determination $R^{2}$ of regression lines of FRV in function of vehicle technical features.

\begin{tabular}{|c|c|c|c|c|c|c|c|c|c|c|}
\hline & \multicolumn{10}{|c|}{ Coefficient of Determination $R^{2}$} \\
\hline & \multicolumn{2}{|c|}{$F R V_{F T P 72}$} & \multicolumn{2}{|c|}{$F R V_{J C 08}$} & \multicolumn{2}{|c|}{$F R V_{N E D C}$} & \multicolumn{2}{|c|}{$F R V_{\text {WLTC }}$} & \multicolumn{2}{|c|}{$F R V_{\text {MeanCycles }}$} \\
\hline & PMR & SE & PMR & SE & PMR & SE & PMR & SE & PMR & SE \\
\hline $\begin{array}{c}\text { Maximum Brake Mean } \\
\text { Effective Pressure }\left(B M E P_{\text {max }} \text { ) }\right.\end{array}$ & 0.55 & 0.68 & 0.61 & 0.71 & 0.40 & 0.69 & 0.57 & 0.67 & 0.57 & 0.73 \\
\hline Vehicle mass $\left(m_{v e h}\right)$ & 0.45 & 0.36 & 0.46 & 0.41 & 0.53 & 0.43 & 0.59 & 0.21 & 0.53 & 0.37 \\
\hline Maximum Power $\left(P_{\max }\right)$ & 0.79 & 0.78 & 0.78 & 0.80 & 0.74 & 0.82 & 0.78 & 0.55 & 0.83 & 0.78 \\
\hline Power-to-Mass Ratio (PMR) & 0.65 & 0.72 & 0.66 & 0.73 & 0.56 & 0.75 & 0.58 & 0.57 & 0.66 & 0.74 \\
\hline
\end{tabular}

The values of $\mathrm{R}^{2}$ in Table 5 show that, for both PMR and SE, a significant correlation between FRV and vehicle technical features exists. $R^{2}$ varies depending on driving cycle:

- $\quad$ The highest correlation is for $P_{\max } . \mathrm{R}^{2}$ is about 0.8 for all cycles (except $F R V_{\text {WLTC_SE }}$ for which it is 0.55 ) with a value of 0.83 and 0.78 , respectively, for $F R V_{\text {MeanCycles_PMR }}$ and FRV $V_{\text {MeanCycles_SE; }}$;

- The lowest correlation is for $m_{v e h}\left(R^{2}\right.$ ranges between a minimum of 0.21 for $F R V_{\text {WLTC_SE }}$ and a maximum of 0.59 for $F R V_{\text {WLTC_PMR }}$ );

- $\quad$ Intermediate values of $\mathrm{R}^{2}$ refer to PMR and BMEP.

\subsection{Environmental Modelling}

The environmental modelling converts mass saving to impact reduction through the implementation of the FRV coefficient within the basic equations of TTW process; the added value is represented by the fact that parameters which characterize TTW process (see Section 2.3) are customizable for the specific application. In particular, the possibility of setting the FRV allows performing the quantification of impact reduction taking into account technical features of the specific case study; therefore, impacts saving is determined more accurately with respect to comparative studies that assume a value for the FRV fixed a priori. Based on the entirety of FRVs obtained for the various case studies, a criterion able to deduce a value customized for any generic application is defined; therefore, simulation and environmental modelling are merged and the output of the first one represents the input for the second one. The chosen approach struggles to take into account the variability of FRV with respect to the main vehicle technical features. Based on values of $\mathrm{R}^{2}$ reported in Table 5, it can be stated that, for both PMR and SE, the correlation between FRV and the chosen technical features is notable and it is maximum for parameter $P_{\max }$. In the light of these considerations, the refined approach for quantifying the FRV for any generic application is the same for both PMR and SE:

- $\quad$ PMR: the FRV is obtained from the regression line of $F R V_{\text {MeanCycles_PMR }}$ in function of $P_{\max }$ through the maximum power of the generic application (see Figure 3);

- $\quad$ SE: The FRV is obtained from the regression line of $F R V_{\text {MeanCycles_SE }}$ in function of $P_{\max }$ through the maximum power of the generic application (see Figure 3).

Table 6 summarizes the chosen approach in order to quantify the FRV for any generic vehicle case study.

Table 6. Input for environmental modelling: criterion for quantifying the FRV of any generic vehicle case study.

\begin{tabular}{ccc}
\hline \multicolumn{3}{c}{$F R V(\mathbf{L} / \mathbf{1 0 0} \mathbf{~ k m} \cdot \mathbf{1 0 0} \mathbf{~ k g})$} \\
\hline PMR & SE \\
\hline$F R V_{P M R}=0.0005 \times P_{\max }+0.1091$ & & $F R V_{S E}=0.0009 \times P_{\max }+0.1721$ \\
\hline & Notes: $P_{\max }$ in $(\mathrm{kW})$. \\
\hline
\end{tabular}


With respect to basic equations of TTW process (see Table 3), the following observations are made:

- The amount of FC saved during operation $\left(F C_{\text {use_sav }}\right)$ has a leading role in the economy of the overall plan. On the one hand, $F C_{\text {use_sav }}$ fixes the amount of fuel whose avoided production is assessed by WTT process. On the other hand, $F C_{\text {use_sav }}$ determines the amount of TTW air emissions saved during operation (see Equations (7)-(15));

- $\quad F C_{\text {use_sav }}$ scales linearly with the saved mass on the basis of the FRV coefficient;

- The amount of air emissions saved during operation $\left(\mathrm{CO}_{2 B I O \_u s e \_s a v}, \mathrm{CO}_{2 F O S \_ \text {use_sav }}\right.$, and $\left.\mathrm{SO}_{2 u s e \_s a v}\right)$ scales linearly with the amount of FC saved during operation $\left(F C_{\text {use_sav }}\right)$;

- Considering the typology of air emissions, only $\mathrm{CO}_{2}$ and $\mathrm{SO}_{2}$ are taken into account. Such a choice appears to be reasonable because FC saving involved by mass reduction only influences $\mathrm{CO}_{2}$ and $\mathrm{SO}_{2}$ emissions while it has no effect on the so-called "limited emissions" (i.e., NOx, $\mathrm{HC}$, etc.). Indeed, $\mathrm{CO}_{2}$ and $\mathrm{SO}_{2}$ emissions scale linearly with the amount of $\mathrm{FC}$ basing on fuel $\mathrm{C}$ and $\mathrm{S}$ content while the limited emissions depend exclusively on the number of travelled kilometres as they are treated by exhaust gas treatment system.

\subsection{Application to Real Case Study}

This section deals with the application of simulation and environmental modelling to a real LCA case study. The chosen application is taken from a comparative lightweight LCA for an automotive component [38]. The assessment is aimed to assess two solutions for an Air Intake Manifold (AIM) which differ in construction material:

- $\quad$ Reference solution: Polyamide reinforced with 30\% of glass fibre, PAGF30 (scenario N 1 in [38]).

- $\quad$ Lightweight solution: Polypropylene composite reinforced with 35\% glass fibre, PPGF35 (scenario N 5 [38]).

The functional unit for the study is the distribution of the appropriate air intake flow to the individual cylinders of a $1300 \mathrm{cc}$ DT engine in order to ensure the correct combustion process of the fuel. The PAGF30 AIM mass is about $1.9 \mathrm{~kg}$ opposite to $1.6 \mathrm{~kg}$ of PPGF35 AIM; therefore, the lightweight solution allows a $18 \%$ mass reduction. For the impact assessment, the following impact categories are adopted: abiotic depletion potential elements (ADPe), abiotic depletion potential fossil (ADPf), acidification potential (AP), eutrophication potential (EP), global warming potential (GWP), ozone layer depletion potential (ODP), and photochemical ozone creation potential (POCP). As reference vehicle for the modelling of use stage, a specific compact car is selected: Table 7 shows its main technical data.

Table 7. Technical data of reference car model for use stage.

\begin{tabular}{cc}
\hline \multicolumn{2}{c}{ FIAT Panda 1.3. MJT (Model Year 2016) } \\
\hline Curb mass $(\mathrm{kg})$ & 1045 \\
Propulsion & Diesel Turbocharged \\
Engine displacement $(\mathrm{cc})$ & 1248 \\
Maximum power $(\mathrm{kW})$ & 70 \\
Emission stage & EURO 6 \\
Mixed consumption $(\mathrm{L} / 100 \mathrm{~km})$ & 3.6 \\
$\mathrm{CO}_{2}$ emissions $(\mathrm{g} / \mathrm{km})$ & 94 \\
$\mathrm{SO}_{2}$ emissions $(\mathrm{g} / \mathrm{km})$ & $6.42 \times 10^{-4}$ \\
Use stage $(\mathrm{km})$ & 150,000 \\
\hline
\end{tabular}

Considering that weight reduction represents a negligible share of total car mass, for the modelling of use stage it is assumed to take into account only the case of PMR, FRV is determined through the criterion defined in Section 3.2 (equation for $F R V_{P M R}$ in Table 6) and it amounts to $0.144 \mathrm{~L} / 100 \mathrm{~km} \times 100 \mathrm{~kg}$. 
Figure 4 reports total LC impact of lightweight solution expressed as percentage of the one of reference solution. Results show that lightweight solution involves a notable reduction of the AIM LC impacts. The highest reduction ( $40 \%)$ regards AP, while, for ADPe, the benefit is negligible ( $3 \%)$; the other categories present reductions that range between $27 \%$ and $35 \%$. Figures 5 and 6 report contribution analysis by LC stage of potential environment impact, respectively, for polyamide and polypropylene composite AIM. Data show that the change of construction material causes a notable growth of use stage quota for the majority of impact categories $(15 \%-20 \%)$, totally to the detriment of production. This fact can be explainable through the minor energy intensity of polypropylene composite production processes despite the lower mass. EoL quotas present a moderate increase (maximum increase is $6 \%$ for $\mathrm{EP}$ ).

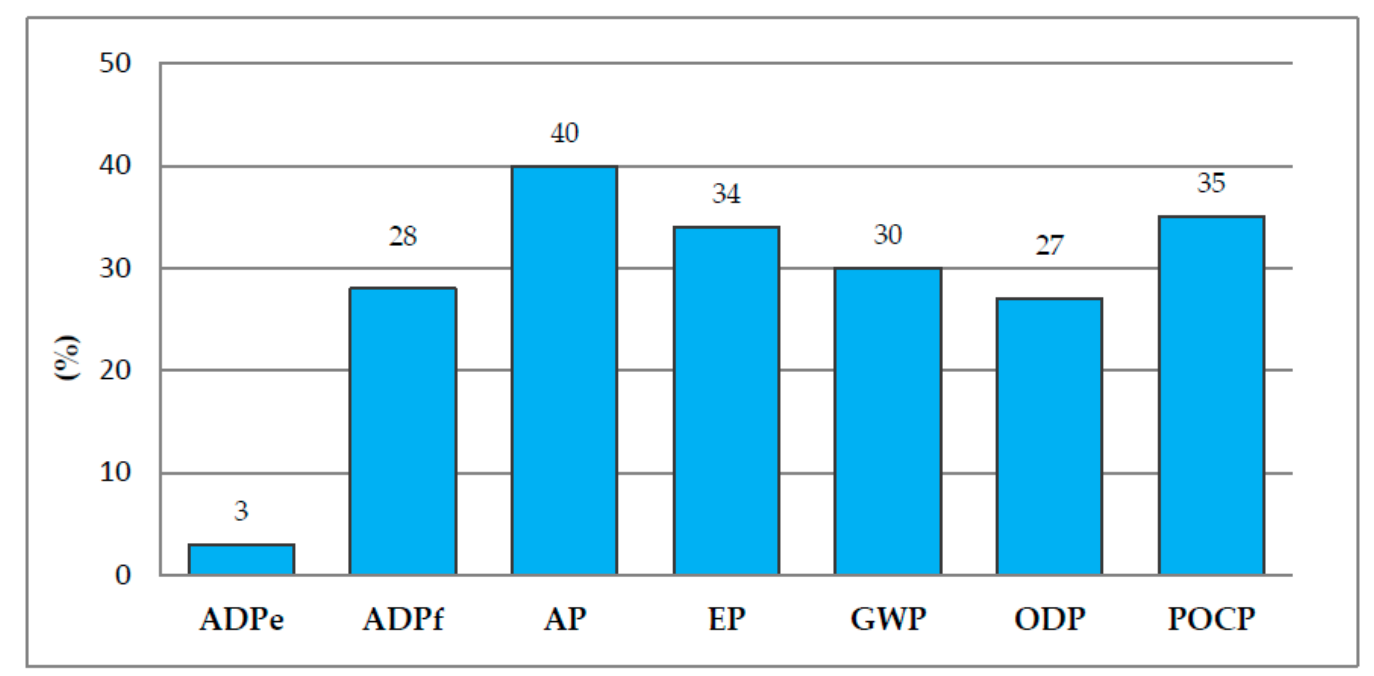

Figure 4. LCA results for polypropylene composite AIM (PPGF35 AIM) expressed as percentage of polyamide composite AIM (PAGF30 AIM)

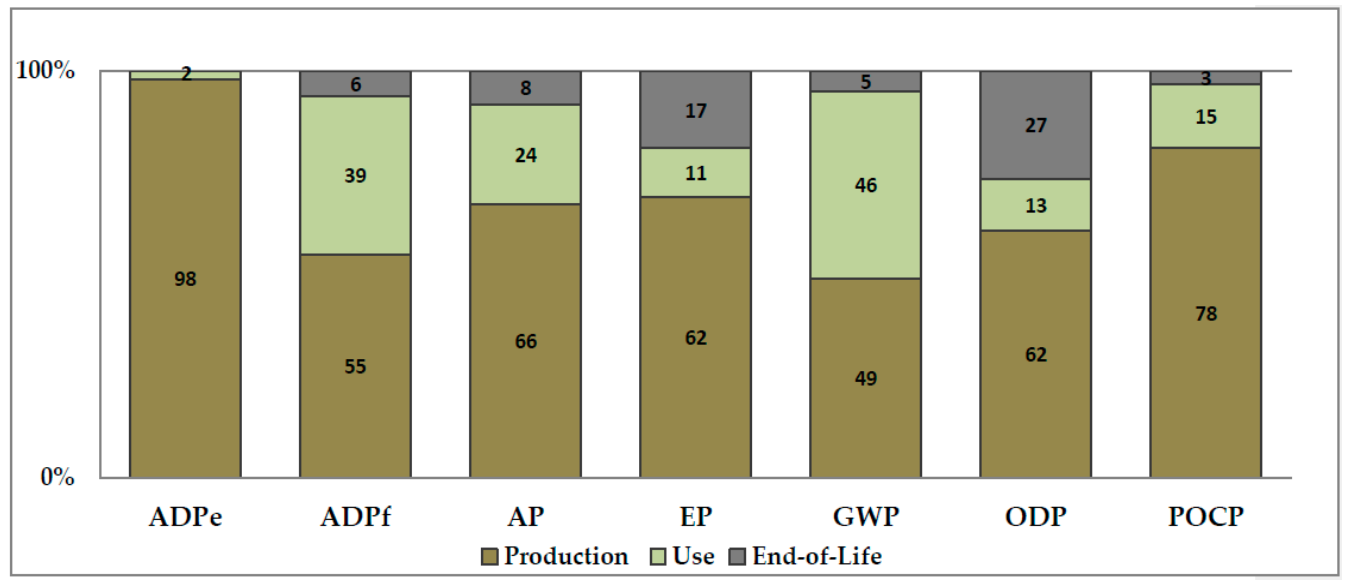

Figure 5. Contribution analysis by LC stage for polyamide composite AIM. 


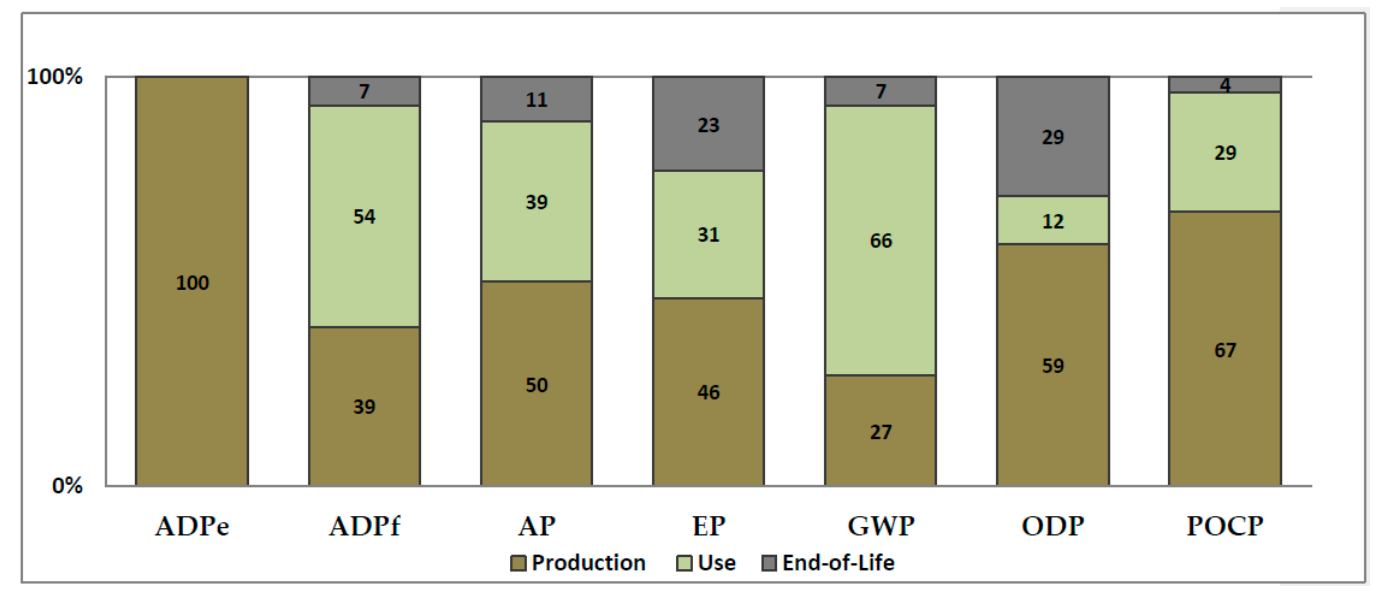

Figure 6. Contribution analysis by LC stage for polypropylene composite AIM.

\section{Conclusions}

This work refines a tool for the assessment of environmental benefits achievable by lightweight design solutions in the automotive field. The tool is obtained through the integration of a simulation and environmental modelling in LCA perspective and it is based on the estimation of FC reduction achievable by "light-weighting" by means of the FRV coefficient. The FRV is determined through a simulation modelling of entire vehicle drivetrain; this allows taking into account all car energy expenditures and evaluating the effect that each drivetrain component has on FC and, consequently, on FRV. As input for the modelling, data of 32 DT vehicle case studies taken from 2015 European car market are gathered and elaborated; the wide range of case studies enables examining as much as possible in detail each specific application, thus obtaining more accurate results with respect to current FRV-based approaches. The calculation is based on four standardized driving cycles, allowing both comparison with existing studies and evaluation of use stage basing on various driving styles. For the estimation of impacts reduction, a model based on the FRV and customizable for any generic application is refined; this is done by taking into account the value of FRV closest to the specific application in terms of vehicle class, size and technical features. The remarkable modularity of the model allows balancing the opposite effects that light-weighting involves on LC stages (higher energy-intensity/emissions during production and reduced FC during operation); in this regard, the possibility to set LC mileage within the environmental modelling allows determining the break-even mileage for the effective environmental convenience of innovative solutions with respect toreference ones.

Author Contributions: Massimo Delogu and Marco Pierini conceived the activity and supervised the work; Massimo Delogu and Marco Pierini performed a critical analysis of the results and revised the paper; Francesco Del Pero conceived, designed and performed the experiments; Francesco Del Pero wrote the paper.

Conflicts of Interest: The authors declare no conflict of interest.

\section{References}

1. Hawkins, T.R.; Singh, B.; Majeau-Bettez, G.; Stromman, A.H. Comparative environmental life cycle assessment of conventional and electric vehicles. J. Ind. Ecol. 2012, 17, 53e64. [CrossRef]

2. Witik, R.A.; Payet, J.; Michaud, V.; Ludwig, C.; Manson, J.A.E. Assessing the life cycle costs and environmental performance of lightweight materials in automobile applications. Compos. Part A 2011, 42, 1694-1709. [CrossRef] 
3. Solomon, S.D.; Qin, M.; Manning, Z.; Chen, M.; Marquis, K.B.; Averyt, M.T.; Miller, H.L. (Eds.) Climate Change 2007: The Physical Science Basis—Contribution of Working Group I to the Fourth Assessment Report of the Intergovernmental Panel on Climate Change; Cambridge University Press: Cambridge, UK; New York, NY, USA, 2007.

4. The Core Writing Team; Pachauri, R.K.; Reisinger, A. (Eds.) Climate Change 2007: The Synthesis Report-Contribution of Working Groups I, II and III to the Fourth Assessment Report of the Intergovernmental Panel on Climate Change; Intergovernmental Panel on Climate Change: Geneva, Switzerland, 2007.

5. World Business Council for Sustainable Development (WBCSD). Mobility 2030: Meeting the Challenges to Sustainability-The Sustainable Mobility Project. Available online: https:/ /www.oecd.org/sd-roundtable/ papersandpublications/39360485.pdf (accessed on 24 March 2016).

6. Berzi, L.; Delogu, M.; Pierini, M. A comparison of Electric Vehicles use-case scenarios-Application of a simulation framework to vehicle design optimization and energy consumption assessment. In Proceedings of the 17th IEEE International Conference on Environment and Electrical Engineering, Florence, Italy, 7-10 June 2016.

7. Dattilo, C.A.; Delogu, M.; Berzi, L.; Pierini, M. A sustainability analysis for Electric Vehicles Batteries including aging phenomena. In Proceedings of the 17th IEEE International Conference on Environment and Electrical Engineering, Florence, Italy, 7-10 June 2016.

8. Moawad, A.; Sharer, P.; Rousseau, A. Light-Duty Vehicle Fuel Consumption Displacement Potential up to 2045; ANL/ESD/11-4; Argonne National Laboratory: Lemont, IL, USA, 2013.

9. O'Neill, B.C.; Oppenheimer, M. Climate change: Dangerous climate impacts and the Kyoto Protocol. Science 2002, 296, 1971-1972. [CrossRef] [PubMed]

10. Steffen, W.; Noble, I.; Canadell, J.; Apps, M.; Schulze, E.-D.; Jarvis, P.G. The terrestrial carbon cycle: Implications for the Kyoto Protocol. Science 1998, 280, 1393-1394.

11. Schmidt, W.P.; Dahlqvist, E.; Finkbeiner, M.; Krinke, S.; Lazzari, S.; Oschmann, D.; Pichon, S.; Thiel, C. Life cycle assessment of lightweight and end-of-life scenarios for generic compact class veh icles. Int. J. Life Cycle Assess. 2004, 9, 405-416. [CrossRef]

12. Koffler, C. Automobile Produkt-Ökobilanzierung. Master's Thesis, Technische Universität Darmstadt, Darmstadt, Germany, 2007.

13. Koffler, C.; Rodhe-Branderburger, K. On the calculation of fuel savings through lightweight design in automotive life cycle assessments. Int. J. Life Cycle Assess. 2010, 15, 128-135. [CrossRef]

14. Ribeiro, C.; Ferreira, J.V.; Partidàrio, P. Life Cycle Assessment of a multi-material car component. Int. J. Life Cycle Assess. 2007, 5, 336-345. [CrossRef]

15. Nemry, F.; Leduc, G.; Mongelli, I.; Uihlein, A. Environmental Improvement of Passenger Cars, (IMPRO-car); Joint Research Center, European Commission: Brussels, Belgium, 2008.

16. Rodhe-Branderburger, K.; Obernolte, J. $\mathrm{CO}_{2}$-Potential durch Leichtbau in Pkw. Mater. Test. 2008, 51, 55-63. [CrossRef]

17. Siskos, P.; Capros, P.; De Vita, A. $\mathrm{CO}_{2}$ and energy efficiency car standards in the EU in the context of a decarbonisation strategy: A model-based policy assessment. Energy Policy 2015, 84, 22-34. [CrossRef]

18. Stichling, J. Life cycle considerations for lightweight automotive design. In Proceedings of the International Conference: Innovative Developments for Lightweight Vehicle Structures, Wolfsburg, Germany, 26-27 May 2009; pp. 209-218.

19. Berzi, L.; Delogu, M.; Pierini, M. Development of driving cycles for electric vehicles in the context of the city of Florence. Transp. Res. Part D Transp. Environ. 2016, 47, 299-322. [CrossRef]

20. Kim, H.C.; Wallington, T.J. Life-cycle energy and greenhouse gas emission benefits of lightweight in automobiles: Review and harmonization. Environ. Sci. Technol. 2013, 47, 6089-6097. [CrossRef] [PubMed]

21. Kelly, J.C.; Sullivan, J.L.; Burnham, A.; Elgowainy, A. Impacts of Vehicle Weight Reduction via Material Substitution on Life-Cycle Greenhouse Gas Emissions. Environ. Sci. Technol. 2015, 49, 12535-12542. [CrossRef] [PubMed]

22. Mayyas, A.T.; Qattawi, A.; Mayyas, A.R.; Omar, M. Quantifiable measures of sustainability: A case study of materials selection for eco-lightweight auto-bodies. J. Clean. Prod. 2013, 40, 177-189. [CrossRef]

23. Raugei, M.; Morrey, D.; Hutchinson, A.; Winfield, P. A coherent life cycle assessment of a range of lightweight strategies for compact vehicles. J. Clean. Prod. 2015, 108, 1168-1176. [CrossRef] 
24. Berzi, L.; Delogu, M.; Giorgetti, A.; Pierini, M. On-field investigation and process modelling of End-of-Life Vehicles treatment in the context of Italian craft-type Authorized Treatment Facilities. Waste Manag. 2013, 33, 892-906. [CrossRef] [PubMed]

25. Berzi, L.; Delogu, M.; Pierini, M.; Romoli, F. Evaluation of the end-of-life performance of a hybrid scooter with the application of recyclability and recoverability assessment methods. Resour. Conserv. Recycl. 2016, 108, 140-155. [CrossRef]

26. Ciacci, L.; Marselli, L.; Passarini, F.; Santini, A.; Vassura, I. A comparison among different automotive shredder residue treatment processes. Int. J. Life Cycle Assess. 2010, 15, 896-906. [CrossRef]

27. Das, S. The Life-Cycle Impacts of Aluminium Body-in-White Automotive Material. J. Miner. Met. Mater. Soc. 2000, 52, 41-44. [CrossRef]

28. Funazaki, A.; Taneda, K.; Tahara, K.; Inaba, A. Automobile life cycle assessment issues at end-of-life and recycling. JSAE Rev. 2003, 24, 381-386. [CrossRef]

29. Delogu, M.; Zanchi, L.; Maltese, S.; Bonoli, A.; Pierini, M. Environmental and Economic Life Cycle Assessment of a lightweight solution for an automotive component: A comparison between talc-filled and hollow glass microspheres-reinforced polymer composites. J. Clean. Prod. 2016, 139, 548-560. [CrossRef]

30. Geyer, R. Parametric Assessment of Climate Change Impacts of Automotive Material Substitution. Environ. Sci. Technol. 2008, 18, 6973-6979. [CrossRef]

31. Grujicic, M.; Sellappan, V.; He, T.; Seyr, N.; Obieglo, A.; Erdmann, M.; Holzleitner, J. Total Life Cycle-Based Materials Selection for Polymer Metal Hybrid Body-in-White Automotive Components. J. Mater. Eng. Perform. 2009, 18, 111-128. [CrossRef]

32. Kim, K.H.; Joung, H.T.; Nam, H.; Seo, Y.C.; Hong, J.H.; Yoo, T.W.; Lim, B.S.; Park, J.H. Management status of end-of-life vehicles and characteristics of automobile shredder residues in Korea. Waste Manag. 2004, 24, 533-540. [CrossRef] [PubMed]

33. Rajendran, S.; Scelsi, L.; Hodzic, A.; Soutis, C.; Al-Maadeed, M.A. Environmental impact assessment of composites containing recycled plastics. Resour. Conserv. Recycl. 2012, 60, 131-139. [CrossRef]

34. Zanchi, L.; Delogu, M.; Ierides, M.; Vasiliadis, H. Life cycle assessment and life cycle costing as supporting tools for EVs lightweight design. Smart Innov. Syst. Technol. 2016, 52, 335-348.

35. Del Pero, F.; Delogu, M.; Pierini, M.; Bonaffini, D. Life Cycle Assessment of a heavy metro train. J. Clean. Prod. 2015, 87, 787-799. [CrossRef]

36. Finkbeiner, M.; Hoffmann, R. Application of Life Cycle Assessment for the Environmental Certificate of the Mercedes-Benz S-Class (7 pp). Int. J. Life Cycle Assess. 2006, 11, 240-246. [CrossRef]

37. Koffler, C. Life cycle assessment of automotive lightweight through polymers under US boundary conditions. Int. J. Life Cycle Assess. 2013, 19, 538-545. [CrossRef]

38. Delogu, M.; Del Pero, F.; Romoli, F.; Pierini, M. Life cycle assessment of a plastic air intake manifold. Int. J. Life Cycle Assess. 2015, 20, 1429-1443. [CrossRef]

39. Delogu, M.; Del Pero, F.; Berzi, L.; Pierini, M.; Bonaffini, D. End-of-Life in the Railway Sector: Analysis of Recyclability and Recoverability for Different Vehicle Case Studies. Available online: http://www. sciencedirect.com/science/article/pii/S0956053X16305396 (accessed on 10 April 2016).

40. Spielmann, M.; Althaus, H.J. Can a prolonged use of a passenger car reduce environmental burdens? Life Cycle analysis of Swiss passenger cars. J. Clean. Prod. 2006, 15, 1122-1134.

41. Alves, C.; Ferrao, P.M.C.; Silva, A.J.; Reis, L.G.; Freitas, M.; Rodrigues, L.B. Ecodesign of automotive components making use of jute fiber composites. J. Clean. Prod. 2010, 18, 313-327. [CrossRef]

42. Du, J.D.; Han, W.J.; Peng, Y.H.; Gu, C.C. Potential for reducing GHG emissions and energy consumption from implementing the aluminum intensive vehicle fleet in China. Energy 2010, 35, 4671-4678.

43. Duflou, J.R.; De Moor, J.; Verpoest, I.; Dewulf, W. Environmental impact analysis of composite use in car manufacturing. CIRP Ann. Manuf. Technol. 2009, 58, 9-12. [CrossRef]

44. Luz, S.; Pires, A.C.; Ferrao, P.M. Environmental benefits of substituting talc by sugarcane bagasse fibres as reinforcement in polypropylene composites: Eco-design and LCA strategy for automotive components. Resour. Conserv. Recyc. 2010, 54, 1135-1144. [CrossRef]

45. Zah, R.; Hischier, R.; Leao, A.L.; Braun, I. Curauà fibers in the automobile industry-A sustainability assessment. J. Clean. Prod. 2006, 15, 1032-1040. [CrossRef]

46. Ridge, L. EUCAR-Automotive LCA guidelines_phase 2, Total Life Cycle Conference and Exposition; SAE Technical Paper 982185; Society of Automotive Engineers (SAE): Graz, Austria, 1997. 
47. Ribeiro, I.; Peças, P.; Silva, A.; Henriques, E. Life Cycle Engineering Methodology Applied to Material Selection, a Fender Case Study. J. Clean. Prod. 2008, 16, 1887-1899. [CrossRef]

48. Subic, A.; Schiavone, F. Design-oriented application of LCA to an automotive system. In Proceedings of the 5th Australian Conference on Life Cycle Assessment, Achieving Benefits from Managing Life Cycle impacts, Melbourne, Austrlia, 22-24 November 2006.

49. Del Pero, F.; Delogu, M.; Pierini, M. Assessing the effect of lightweighting in automotive LCA perspective: Estimation of mass-induced fuel consumption reduction for gasoline turbocharged vehicles. J. Clean. Prod. 2016, submitted.

50. Eberle, R.; Franze, H.A. Modelling the Use Phase of Passenger Cars in LCI; SAE Technical Paper 982179; Society of Automotive Engineers (SAE): Graz, Austria, 1998.

51. Kim, H.C.; Wallington, T.J. Life Cycle Assessment of Vehicle Lightweighting: A Physics-Based Model of Mass-Induced Fuel Consumption. Environ. Sci. Technol. 2013, 47, 14358-14366. [CrossRef] [PubMed]

52. Kim, H.C.; Wallington, T.J.; Sullivan, J.L.; Keoleian, G.A. Life Cycle Assessment of Vehicle Lightweighting: Novel Mathematical Methods to Estimate Use-Phase Fuel Consumption. Environ. Sci. Technol. 2015, 49, 10209-10216. [CrossRef] [PubMed]

53. Pagerit, S.; Sharer, P.; Rousseau, A. Fuel Economy Sensitivity to Vehicle Mass for Advanced Vehicle Powertrains; SAE Paper No. 2006-01-0665; SAE International: Detroit, MI, USA, 2006.

54. Wohlecker, R.; Johannaber, M.; Espig, M. Determination of Weight Elasticity of Fuel Economy for ICE, Hybrid and Fuel Cell Vehicles; SAE Paper No. 2007-01-0343; SAE International: Detroit, MI, USA, 2007.

55. Casadei, A.; Broda, R. Impact of Vehicle Weight Reduction on Fuel Economy for Various Vehicle Architectures. Available online: http://www.drivealuminum.org/wp-content/uploads/2016/07/Ricardo_ Impact-of-Vehicle-Weight-Reduction-on-Fuel-Economy-for-Various-Vehicle-Architectures.pdf (accessed on 7 February 2016).

56. Redelbach, M.; Klotzke, M.; Friedrich, H.E. Impact of lightweight design on energy consumption and cost effectiveness of alternative powertrain concepts. In Proceedings of the European Electric Vehicle Conference, Brüssel, Belgien, 19-22 November 2012.

57. Marotta, A.; Tutuianu, M. Europe-Centric Light Duty Test Cycle and Differences with Respect to the WLTP Cycle; JRC (Joint Research Centre) Scientific and Policy Reports; European Commission: Varese, Italy, 2012.

58. Mock, P. Inertia Classes Proposal. WLTP-DTP-LabProcICE-077. Submission to the UNECE GRPE Informal Subgroup on the Development of a Worldwide Harmonized Light Vehicles Test Procedure (WLTP-DTP). Available online: http://www.theicct.org/sites/default/files/publications/WLTP_inertia_workingpaper_ 2011.pdf (accessed on 2 March 2016).

59. Tutuianu, M.; Marotta, A.; Steve, H.; Ericsson, E.; Haniu, T.; Ichikawa, N.; Ishii, H. Development of a World-Wide Worldwide Harmonized Light Duty Driving Test Cycle (WLTC). Available online: https://www.unece.org/fileadmin/DAM/trans/doc/2013/wp29grpe/GRPE-67-03.pdf (accessed on 24 March 2016).

60. United States Environmental Protection Agency (EPA) Home Page. Available online: http:/ /www3.epa.gov / (accessed on 18 January 2015).

61. United Nations Economic Commission for Europe (UNECE) Home Page. Available online: http://www. unece.org/trans/welcome.html (accessed on 4 March 2015).

62. Barlow, T.J.; Latham, S.; McCrae, I.S.; Boulter, P.G. A Reference Book of Driving Cycles for Use in the Measurement of Road Vehicle Emissions; TRL Published Project Report; TRL (Transport Research Laboratory): Berkshire, UK, 2009.

63. Kuhlwein, J.; German, J.; Baudiradekar, A. Development of Test Cycle Conversion among Worldwide Light-Duty Vehicle $\mathrm{CO}_{2}$ Emission Standard. Available online: http:/ /www.theicct.org/sites/default/ files / publications/ICCT_LDV-test-cycle-conversion-factors_sept2014.pdf (accessed on 3 April 2016).

(C) 2016 by the authors; licensee MDPI, Basel, Switzerland. This article is an open access article distributed under the terms and conditions of the Creative Commons Attribution (CC-BY) license (http://creativecommons.org/licenses/by/4.0/). 